УДК 342.951.02:342.5(477)

\author{
Д. В. Бараненко \\ orcid.org/0000-0003-0234-7561 \\ кандидат юридичних наук
}

\title{
ПРОБЛЕМИ ТА ПЕРСПЕКТИВИ РЕАЛІЗАЦЇ̈ ЕЛЕКТРОННОГО УРЯДУВАННЯ В ДІЯЛЬНОСТІ ЦЕНТРАЛЬНИХ ОРГАНІВ ВИКОНАВЧОЇ ВЛАДИ
}

Постановка проблеми. Електронне урядування в Україні стало невід'ємною частиною політико-правової дискусії. Запроваджуючи його, органи публічної адміністрації намагаються досягти відповідності сучасним вимогам, продемонструвати власну відкритість та впевнений рух на шляху до подальшої демократизації публічної влади. В органах публічної адміністрації починають функціонувати спеціальні структурні підрозділи, покликані відповідати саме за цей напрям діяльності, активно ухвалюються відповідні нормативно-правові акти. Від упровадження електронного урядування очікується ефект у багатьох напрямах (від значного зростання ефективності використання документообігу до покращення роботи зі зверненнями громадян). Електронний уряд визначається як система взаємодії органів державної влади з населенням, заснована на широкому використанні сучасних інформаційних технологій, зокрема й мережі Інтернет, для підвищення доступності та якості державних послуг, скорочення термінів їх надання, а також ліквідації адміністративного навантаження на громадян і організацій, пов'язаних із їх отриманням. Виявлення змісту і сутності електронного урядування щодо публічного управління дозволяе визначити його як систему інформаційної взаємодії публічної влади із суспільством шляхом поєднання внутрішньої (урядової) та зовнішньої (суспільної) інфраструктур через Інтернет-представництва органів публічної влади, що значно розширює доступність публічно-управлінських послуг та скорочує терміни їх надання.

Аналіз останніх досліджень і публікацій. Питання публічного управління у сфері розвитку електронного урядування досліджувалися такими вітчизняними науковцями, як I.В. Арістова, О.А. Баранов, Н.В. Грицяк, М.С. Демкова, С.В. Дзюба, І.Б. Жиляєв, О.В. Карпенко, П.С. Клімушин, В.О. Коновал, О.Б. Кукарін, В.В. Марченко, А.I. Семенченко, А.О. Серенок та ін., які сходяться в тому, що для успішної реалізації державної політики у сфері розвитку інформаційного суспільства та електронного урядування необхідна її підтримка з боку вищого державного керівництва і наявність політичних інститутів демократичної правової держави, насамперед розвинутих інститутів громадянського суспільства.
Потрібна також наявність дієвої інформаційної інфраструктури та узгодженість процесів упровадження електронного урядування з проведенням адміністративної реформи в країні. Тобто проблема електронного урядування в діяльності центральних органів виконавчої влади залишається вкрай актуальною та потребує подальших досліджень.

Формування цілей. Метою статті є характеристика теоретичних та практичних аспектів реалізації електронного урядування в діяльності центральних органів виконавчої влади.

Виклад основного матеріалу. Електронне урядування як корпоративна система національного, регіонального або відомчого масштабу має кілька аспектів, що відображають його теоретико-методологічні, організаційні, інституційні, нормативно-правові, технологічні та інші основи. Комплексне вивчення цих аспектів є обов'язковою передумовою отримання цілісного системного уявлення про це та оволодіння відповідними знаннями і навичками фахівця організаційних систем електронного урядування будь-якого рівня. Упровадження е-урядування є складним процесом, що потребує значних матеріальних, інтелектуальних і фінансових ресурсів та вирішення комплексу правових, організаційних і технологічних проблем. Серед основних чинників, що гальмують активне запровадження і розвиток різних технологій електронного урядування в системі публічного управління або їх ефективного використання, можна назвати декілька. По-перше, суттєвим чинником є недостатність або ж відсутність системного публічного контролю в цій галузі, а також фактична відсутність єдиної структури публічного управління процесами інформатизації органів публічної адміністрації. По-друге, відчутно впливає дуже слабка взаємодія у функціонуванні інформаційно-комунікаційних систем органів публічної влади та їх відомча відокремленість. По-третє, неефективною залишається державна політика щодо стандартизації, зокрема і в галузі відкритих стандартів, для застосування в процесі надання публічних послуг, кредитно-фінансовій сфері, економіці, електронній комерції, освіті та ін. По-четверте, зберігається невідповідність чинного законодавства у сфері інформаційно-комунікаційних технологій та інформаційної безпеки системі законодавства Європейського Союзу 
[1, с. 89]. Тобто до принципово необхідних кроків до створення системи е-урядування в Україні слід зарахувати розроблення загальнодержавної концепції створення «Електронного урядування» на визначений період. Своєчасно має відбуватися також планування бюджету, що забезпечує необхідні витрати на реалізацію заходів електронного урядування із залученням державних та недержавних джерел. Повинні існувати наукові школи і великі підприємства, що функціонують у сфері інформаційно-комунікаційних технологій, розгалужена інформаційно-технологічна інфраструктура. Але це питання, на наш погляд, залежить від політичної волі керівників органів публічної адміністрації та усвідомлення ними важливості інформаційних ресурсів в умовах формування інформаційного суспільства [2, с. 150].

Таким чином, електронне урядування - це система взаємодії державних інституцій з окремими громадянами та суспільством у цілому через інформаційно-комунікаційні технології, що забезпечує оперативне, відкрите та неупереджене вирішення будь-яких соціально-побутових проблем. Крім того, електронне урядування мінімізуе контакт громадян із чиновниками, тим самим зменшуючи корупційний складник у державному управлінні на національному та регіональному рівнях.

Таким чином, під час запровадження електронного урядування слід обов'язково врахувати ті проблеми, які є найбільш актуальними. Йдеться про актуальність проблеми сумісності, адже різні технології електронного урядування, що впроваджуються в органах публічної влади і в органах місцевого самоврядування, обов'язково мають бути сумісними [3, с. 103]. Можна стверджувати, що без розв'язання цього питання належна ефективна взаємодія як між місцевими, так і центральними органами державної влади, між органами публічної влади і органами місцевого самоврядування не буде можливою.

Результативність запровадження е-врядування в публічному управлінні України має базуватися на врахуванні таких обставин щодо: ліквідації цифрової нерівності в частині забезпечення для всіх громадян однакових рівнів володіння персональними комп'ютерами та однакових можливостей доступу до публічної інформації; усвідомленого розуміння громадянського суспільства, місця і ролі громадянина в управлінні державою, оскільки за умов запровадження електронної демократії на громадянина поширюється відповідальність за прийняті за його участю колективні рішення; формування у громадян довіри до електронних форм комунікацій, до електронної інформації управлінського характеру в частині інформаційної безпеки та гарантованості недоторканості персональних даних; запровадження в публічному управлінні такого важливого та забутого складника, як планування, що дозволить громадянам брати участь в обговоренні плану розвитку на майбутне як інструмента стабільності економічного розвитку [4, с. 89-90].

Слід наголосити, що за останні десятиліття відбувається доволі швидкий розвиток інформаційно-комунікаційних технологій та їх стрімке застосування в публічному управлінні, але все ще не вирішеною залишається проблема недосконалості нормативно-правовоїбази, щозначногальмуєвпровадження окремих складників е-урядування в усі галузі суспільного та державного життя [5, с. 99].

Однією $з$ важливих передумов створення й ефективного функціонування електронного уряду $є$ його належне нормативно-правове забезпечення. Воно має спрямовуватись на врегулювання суспільних відносин, що виникають у сфері інформатизації в тій іï частині, яка забезпечує інформаційні потреби всього суспільства, захищає права споживачів е-послуг, установлює компетенції, а також координуе діяльність органів публічної адміністрації в умовах існування е-урядування. Відчувається потреба в документах, які встановлюють загальні правила, стратегічні напрями і конкретні стандарти стосовно електронного урядування, а також сфери створення і використання інформаційно-комунікаційних технологій у публічному управлінні. Безсумнівно, належна нормативно-правова база дозволить ліквідувати відставання чинного законодавства в цій сфері від суспільних потреб і характеру суспільних відносин, а також створити цілісну національну правову систему, адаптовану до загальновизнаних норм і принципів міжнародного права.

M.М. Газізов електронне урядування трактує як спосіб організації державної влади за допомогою локальних інформаційних мереж та сегментів глобальної інформаційної мережі, що забезпечує функціонування органів влади в режимі реального часу та робить максимально простим і доступним щоденне спілкування з ними громадян, юридичних осіб, неурядових організацій [6, с. 118]. С.О. Гайдученко стверджує, що е-уряд - це своєрідна адаптація публічного управління до сучасних вимог суспільного розвитку, що включає як безпосередньо публічні послуги, які надаються громадянам органами публічної влади та місцевого самоврядування, так і активну взаємодію між ними завдяки підтримці та забезпеченню системи зворотного зв'язку за допомогою сучасних інформаційно-комунікаційних технологій [7, с. 8-9]. Під електронним урядуванням І.Б. Жиляяєв та A.I. Семенченко розуміють форму організації публічного управління, яка, широко застосовуючи новітні інформаційно-комунікаційні технології, забезпечує якісно новий рівень відкритої взаємодії держави та суспільства, надання повного комплексу державних послуг для всіх категорій гро- 
мадян та суб'єктів господарювання [8, с. 18-19]. М.С. Міхровська зазначає, що становлення електронного урядування як невід'ємного елементу процесу здійснення публічної влади значно наблизить Україну до якісних демократичних стандартів діяльності публічної адміністрації, сприятиме зростанню рівня прозорості органів виконавчої влади, покращить ефективність їх діяльності, тобто допомагатиме належному забезпеченню в Україні захисту прав і свобод людини і громадянина [9, с. 74-75].

Нормативно-правові передумови функціонування електронного урядування базуються на чинному законодавстві у сфері інформаційних відносин і захисту інформації. Сьогодні сферу електронного урядування та інфраструктуру інформаційно-комунікаційних технологій в Україні загалом регулює достатня кількість нормативно-правових актів.

На сайті Верховної Ради України є нормативно-правові акти щодо інформатизації (з 1993 р.). У лютому 1998 р., як відомо, було ухвалено закони України «Про Національну програму інформатизації» [10] та «Про Концепцію Національної програми інформатизації» [11]. Серед нормативних документів, затверджених до цієї дати, слід згадати укази Президента України «Про утворення Національного агентства з питань інформатизації» [12], «Про заходи щодо забезпечення діяльності Національного агентства з питань інформатизації», «Про Положення про Державний комітет зв'язку України», а також постанови Кабінету Міністрів України «Питання інформатизації, «Про Національне агентство з питань інформатизації при Президентові України». Отже, у питаннях державної політики інформатизації спостерігається керівна роль Президента України. Уряд задля виконання вищезазначених указів опікувався реалізацією політики інформатизації. У Концепції Національної програми інформатизації словосполучення «електронне урядування» не застосовується, проте з її тексту можна побачити, які конкретні кроки законодавець мав на увазі щодо розвитку електронного урядування в Україні.

Перше згадування терміна «електронне урядування» у вітчизняному законодавстві міститься в урядових документах: в розпорядженні Кабінету Міністрів України «Про затвердження Концепції формування системи національних електронних інформаційних ресурсів» [13] та в Доповіді Кабінету Міністрів України парламенту України про стан та розвиток інформатизації в Україні за 2003 р. (в ньому саме запровадження технологій електронного урядування було визначено важливим напрямом розвитку нормативно-правової бази сфери інформатизації у 2003 р.).
У Концепції формування системи національних електронних інформаційних ресурсів указується, що саме останні і є важливим елементом стратегічних державних ресурсів, а їх значення зростає разом із розвитком інформаційних технологій та їх використанням у різних галузях суспільного життя. Ефективне публічне управління національними ресурсами інформації в такому разі стає запорукою забезпечення інформаційної безпеки держави та реалізації державної політики в галузі інформатизації.

У 2007 р. було ухвалено Закон України «Про Основні засади розвитку інформаційного суспільства в Україні на 2007-2015 роки» [14]. Пізніше розпорядженням Кабінету Міністрів України було затверджено план заходів із виконання завдань, передбачених цим законом. У Розділі III Закону України «Про Основні засади розвитку інформаційного суспільства в Україні на 2007-2015 роки» вказується, що Національна політика розвитку інформаційного суспільства в Україні передбачає декілька напрямів. По-перше, перехід до пріоритетного науково-технічного та інноваційного розвитку (що потребує, зокрема, впровадження інформаційно-комунікаційних технологій у всі сфери життєдіяльності суспільства i держави; створення електронних інформаційних ресурсів, які повинні використовуватись в інформаційному обміні). По-друге, потрібно сприяти збільшенню кількості та різноманітності електронних послуг (з цією метою слід визначити правовий статус і вичерпний перелік обов'язкових електронних публічних послуг, які повинні надаватись органами публічної адміністрації та органами місцевого самоврядування фізичним і юридичним особам. По-третє, необхідно забезпечити реалізацію принципу «єдиного вікна» і створення загальнодоступних електронних ресурсів інформації (що сприятиме демократичним перетворенням суспільства шляхом забезпечення доступу населення до ресурсів інформації і систем надання інформаційних послуг органами публічної адміністрації та органами місцевого самоврядування із застосуванням мережі Інтернет) [15].

Із метою впровадження в діяльність органів публічної адміністрації системи електронної взаємодії органів виконавчої влади в 2011-2012 pp. Кабінетом Міністрів України 28 грудня 2011 р. було ухвалено спеціальне розпорядження «Питання впровадження системи електронної взаємодії органів виконавчої влади», а потім і постанову «Деякі питання електронної взаємодії органів виконавчої влади" від 18 липня 2012 р. А у другій половині 2012 р. Кабінетом Міністрів України схвалено Концепцію створення та функціонування інформаційної системи електронної взаємодії державних електронних ресурсів інформації, що 
мала стати головним елементом системи електронного урядування. Трохи пізніше, 11 липня 2013 р., розпорядженням Кабінету Міністрів України затверджено план заходів щодо її реалізації, а вже у 2016 р. - положення про таку систему.

15 травня 2013 р. розпорядженням Кабінету Міністрів України було схвалено Стратегію розвитку інформаційного суспільства в Україні, розраховану до 2020 р. У ньому електронне урядування визначалося як один із головних напрямів її реалізації, а основними засадами розвитку електронного урядування, відповідно до Закону України «Про Основні засади розвитку інформаційного суспільства в Україні на 2007-2015 роки», Закону України «Про Національну програму інформатизації» та Концепції розвитку електронного урядування в Україні, у Стратегії розвитку інформаційного суспільства в Україні були вказані такі: створення сучасного нормативно-правового забезпечення; активне розроблення та впровадження концептуальних засад інтегрованої системи «Електронний Уряд»; підвищення ефективності та якості адміністративних послуг населенню, що надаються за допомогою інформаційно-комунікаційних технологій; формування системи електронної взаємодії публічних органів влади; створення Єдиного державного порталу адміністративних послуг із метою забезпечення надання органами виконавчої влади та іншими органами публічної адміністрації, а також органами місцевого самоврядування адміністративних послуг громадянам та організаціям тощо.

У серпні 2013 р. була схвалена Концепція створення та функціонування автоматизованої системи «Єдине вікно подання електронної звітності» . План заходів щодо її реалізації затверджено окремим розпорядженням Кабінету Міністрів України [16] При цьому варто зазначити, що бюджетні кошти виділялись на її розбудову ще з 2011 р.

Сьогодні ж відбувається поступова реалізація положень (зокрема й щодо розвитку електронного урядування) Стратегії реформування державного управління України на 2016-2020 рр., схваленої розпорядженням Кабінету Міністрів України [17]. Заслуговує на увагу і важливість такого документа, як План пріоритетних дій Уряду на 2016 рік, затверджений розпорядженням Кабінету Міністрів України [18] Крім того, на стадії обговорення перебуває Середньостроковий план пріоритетних дій Уряду на період до 2020 р., у якому в окремому підрозділі наведено заходи щодо подальшого розвитку електронного врядування в Україні.

Висновки. Таким чином, успішність процесу запровадження е-врядування в діяльності центральних органів виконавчої влади повинна базуватись на врахуванні багатьох обставин. Це стосується насамперед необхідності ліквідації цифрової нерівності в частині забезпечення для всіх грома- дян однакових рівнів користування персональними комп'ютерами та рівних можливостей доступу до джерел публічної інформації. Ідеться і про усвідомлене розуміння громадянського суспільства, місця і ролі окремого громадянина в публічному управлінні, оскільки в умовах запровадження електронної демократії на громадянина розповсюджується відповідальність за прийняті за його участю публічно-управлінські рішення. Потрібно формувати у громадян довіру до електронних форм комунікацій, до електронної інформації публічно-управлінського характеру, зокрема й щодо інформаційної безпеки та гарантованості недоторканості персональних даних. Необхідним також є запровадження в публічному управлінні дуже важливого складника - планування, що дозволить громадянам брати активну участь в обговоренні плану розвитку на майбутнє як інструмента стабільності суспільного розвитку.

\section{Jimepamypa}

1. Семенченко А.І., Власенко Р.В. Теоретико-методологічні основи організаційно-правових механізмів навчання публічних службовців електронному урядуванню. Аспекти публічного управління. 2015. № 1-2. C. $88-95$.

2. Мазур О.Г. Сучасні тенденції упровадження електронного урядування в публічному управлінні: зарубіжний досвід. Аспекти публічного управління. 2019. T. 7, № 12. С. 147-156.

3. Сопілко I.M., Сай P.Є. Електронне урядування, як елемент електронної демократії в Україні. Юридичний вісник. Повітряне і космічне право. 2020. № 2. C. 102-107.

4. Загуменник В.I., Проценко В.В. Державне управління та виконавча влада в Україні : навч. посіб.; за заг. ред. акад. Нац. акад. прав. наук України О.Д. Крупчана. Бендери : Поліграфіст. Київ, 2015. 295 с.

5. Особливості публічного управління та адміністрування : навч. посіб. / Бакуменко В.Д., Бондар I.С., Горник В.Г. та ін. Київ : Ліра-К, 2016. 256 с.

6. Газізов М.M. Електронне урядування як один із провідних напрямів сучасної державної політики. Держава і право. Серія : Політичні науки. 2018. Вип. 80. C. $113-125$.

7. Гайдученко С.О. Управлінські рішення в умовах публічного менеджменту та електронного урядування: лідерський аспект. Університетські наукові записки. 2019. № 4. С. 6-17.

8. Жиляєв І.Б., Семенченко А.І. Етапи розвитку електронного урядування: сутність та термінологія. Теорія та практика державного управління. 2019. Вип. 1. С. 17-28.

9. Міхровська М.С. Адміністративно-правове забезпечення організації та діяльності органів виконавчої влади в Україні : дис. ... канд. юрид. наук : 12.00.07. Київ. 2015. 210 с.

10. Про Національну програму інформатизації : Закон України від 4 лютого 1998 р. № 74/98-ВР. URL: http://www.zakon.rada.gov.ua.

11. Про Концепцію Національної програми інформатизації : Закон України від 4 лютого 1998 р. № 75/98-BP. URL: http://www.zakon.rada.gov.ua.

12. Про утворення Національного агентства 3 питань інформатизації : Указ Президен- 
та України від 13 березня 1995 р. № 206/95. URL: http://www.zakon.rada.gov.ua.

13. Про затвердження Концепції формування системи національних електронних інформаційних ресурсів : розпорядження Кабінету Міністрів України від 5 травня 2003 р. № 259-p. URL: http://www.zakon.rada.gov.ua.

14. Про Основні засади розвитку інформаційного суспільства в Україні на 2007-2015 роки : Закон України від 9 січня 2007 р. № 537-V. URL: http://www.zakon.rada.gov.ua.

15. Про затвердження плану заходів з виконання завдань, передбачених Законом України «Про Основні засади розвитку інформаційного суспільства в Україні на 2007-2015 роки" : розпорядження Кабінету Міністрів України від 15 серпня 2007 р. № 653-р. URL: http://www.zakon.rada.gov.ua.

16. Про затвердження плану заходів щодо реалізації Концепції створення та функціонування автоматизованої системи «Єдине вікно подання електронної звітності» : розпорядження Кабінету Мiністрів України від 17 жовтня 2013 р. № 809-p. URL: http://www.zakon.rada.gov.ua.

17. Про затвердження плану заходів щодо реалізації Концепції створення та функціонування автоматизованої системи «Єдине вікно подання електронної звітності" : розпорядження Кабінету Мiністрів України від 17 жовтня 2013 р. № 809-p. URL: http://www.zakon.rada.gov.ua.

18. Про затвердження плану пріоритетних дій Уряду на 2016 рік : розпорядження Кабінету Міністрів України від 27 травня 2016 р. № 418-p. URL: http://www.zakon.rada.gov.ua.

\section{Анотація}

Бараненко Д. В. Проблеми та перспективи реалізації електронного урядування в діяльності центральних органів виконавчої влади. - Стаття.

У статті досліджено теоретичні та практичні аспекти реалізації електронного урядування в діяльності центральних органів виконавчої влади. Наголошено, що електронне урядування в Україні стало невід'ємною частиною політико-адміністративного дискурсу, за допомогою якої центральні органи виконавчої влади демонструють свою відповідність вимогам часу, відкритість та поступ на шляху до демократизації, створюючи окремі підрозділи, які безпосередньо відповідають за цей напрям діяльності, ухвалюють відповідні нормативно-правові акти. Вказано, що з'ясування сутності електронного урядування дозволяє визначити його як систему інформаційної взаємодії органів публічноі влади із суспільством шляхом поєднання внутрішньої (урядової) та зовнішньої (суспільної) інфраструктур через владні Інтернет-представництва, що значно збільшує рівень доступності публічних послуг та суттєво скорочує строки їх надання. Доведено, що електронне урядування має кілька аспектів, які відображають його теоретико-методологічні, організаційні, інституційні, нормативно-правові, технологічні та інші основи. А комплексне вивчення цих аспектів є обов'язковою передумовою отримання цілісного системного уявлення про нього та опанування відповідних знань i навичок фахівця організаційних систем електронного урядування будь-якого рівня. Підкреслено, що впровадження е-урядування є складним процесом, що потребує значних матеріальних, інтелектуальних і фінансових ресурсів та вирішення комплексу правових, організаційних і технологічних проблем.
Установлено, що електронне урядування є системою взаємодії центральних органів виконавчої влади 3 окремим громадянином та суспільством у цілому через інформаційно-комунікаційні технології. Доведено, що модернізація діяльності центральних органів виконавчої влади втілюється у розробленні і реалізації концепції електронного врядування в Україні, покликаної забезпечити: легкість доступу до інформації про діяльність, структуру, статус, режим роботи, місцезнаходження, результати діяльності центральних органів виконавчої влади; спрощення процедури та можливість електронного звернення до центральних органів виконавчої влади з метою ухвалення рішень, надання адміністративних послуг їх замовникам.

Ключові слова: адміністративно-правові аспекти, виконавча влада, електронне урядування, інформаційно-комунікаційні технології повноваження, публічне управління, сервісна держава, центральний орган виконавчої влади.

\section{Summary}

Baranenko D. $V$. Problems and prospects of e-government implementation in the activity of central executive bodies. - Article.

The article examines the theoretical and practical aspects of the implementation of e-government in the activities of central executive bodies. It is emphasized that e-government in Ukraine has become an integral part of the political-administrative discourse, through which the central executive bodies demonstrate their compliance with the requirements of the time, openness and progress towards democratization, creating separate units responsible for this activity. relevant programs and regulations. It is stated that clarifying the essence of e-government allows to define it as an information system of interaction between government and society based on a combination of internal governmental and external public infrastructure through government Internet representations (portals), which significantly expands the availability of administrative services. It is proved that e-government as a corporate system of departmental scale has several aspects that reflect its theoretical and methodological, organizational, institutional, legal, technological and other foundations. And a comprehensive study of these aspects is a prerequisite for obtaining a holistic systemic view of it and mastering the relevant knowledge and skills of a specialist in organizational systems of e-government at any level. It is emphasized that the introduction of e-government is a complex process that requires significant material, intellectual and financial resources and solutions to a range of legal, organizational and technological problems.

It is established that e-government is a system of interaction of central executive bodies with the individual citizen and society as a whole through information and communication technologies. It is proved that the modernization of central executive bodies is embodied in the development and implementation of the concept of e-government in Ukraine, designed to ensure: ease of access to information about the activities, structure, status, mode of operation, location, results of central executive bodies; simplification of the procedure and the possibility of electronic application to the central executive bodies for decision-making, provision of administrative services to their customers.

Key words: administrative and legal aspects, executive power, e-government, information and communication technologies powers, public administration, service state, central executive body. 